\title{
Acceptance, Effectiveness and Relationship of Blended Learning Implementation Among Lecturers in Polytechnic Sultan Mizan Zainal Abidin.
}

\author{
${ }^{1}$ Hasni bin Mahmood, ${ }^{2}$ Saupi bin Mohamed Noor \\ ${ }^{1}$ Politeknik Sultan Mizan Zainal Abidin \\ ${ }^{2}$ Politeknik Sultan Mizan Zainal Abidin \\ 1'hasni@psmza.edu.my, 22saupi@psmza.edu.my
} \begin{abstract}
cross sectional. PSMZA

Originality/value: This paper is original.

\begin{tabular}{lll}
\hline Received & $:$ December $12^{\text {th }} 2019$ \\
Revised & $:$ February $17^{\text {th }} 2020$ \\
Published & $:$ March $30^{\text {th }} 2020$ \\
\hline
\end{tabular}
\end{abstract}

ABSTRACT

Purpose: This paper aims to analyze Acceptance, Effectiveness and Relationship of Blended Learning Implementation Among Lecturers in Polytechnic Sultan Mizan Zainal Abidin.

Design/methodology/approach: The method used is statistic-descriptive and the design used is

Findings: 2 hypotheses are rejected while the other is accepted.

Research limitations/implications: Variables considered in this study are e-Learning, blended learning, innovation, teaching and online learning. with data showing 270 academic lecturers in

Practical implications: Results show that from the 2 hypotheses proposed.

Paper type: This paper can be categorized as a case study.

Keyword: e-Learning, blended learning, innovation, teaching and online learning

\section{INTRODUCTION}

The National e-Learning Policy (DePAN) has been formulated by the Ministry of Education Malaysia in view of the importance and development of information and communication technology systems in the rapidly expanding educational field in conjunction with the evolution of the economy and industry. The main purpose of the DePAN formulation is to encourage the implementation of e-Learning based teaching and learning methods to be more organized, clear and capable of better mechanisms (Mohamed Amin \& Mohd Najib, 2010).

One of the online learning concepts implemented in Polytechnic Malaysia is Blended Learning or integrated learning. The blended learning approach is one of the methods in e-learning. The concept of blended learning practiced in all Malaysian polytechnics will focus on 21st century pedagogy that combines traditional (face-to-face)

Acceptance, Effectiveness and Relationship of Blended Learning Implementation Among Lecturers in Polytechnic Sultan Mizan Zainal Abidin 
learning and online learning. Moreover, this approach uses the latest digital technology to provide opportunities for the public especially lecturers and students, no matter where they are. Blended Learning refers to courses that have a mix of online and offline learning approaches with $30 \%-80 \%$ online course content and course activities that either support or replace face-to-face learning (CAP eLearning, 2014).

Blended Learning is a concept of mixing conventional learning models with virtual learning through communication information technology (Hussin et al., 2013). By utilizing this concept lecturer can use various teaching and learning methods, different kinds of delivery techniques through virtual learning environment that can trigger a new phenomenon of learning. The integration or blending of such learning should be able to attract students to avoid boredom and lose focus on the subjects they are learning. Blended learning is a method of teaching and learning that combines conventional methods of face-to-face and also uses virtual learning online anywhere at free time and can be referenced at any time (Yu et al., 2014; Gecer, 2013; Osgerby, 2013; Mahajan and Chaturdevi, 2013). Whilst Whitelock and Jefts (2003) points out that blended learning is a blend of traditional (face-to-face) learning with online web approaches, a combination of media and tools used in e-learning environments as well as a combination of several pedagogical approaches regardless learning the use of technology.

Based on the definition and interpretation of blended learning by several previous researchers, it can be concluded here that blended learning emphasizes the integration or integration of learning methods. It is also a teaching and learning method that combines the conventional method of face-to-face and also uses virtual learning online.

Most educational institutions in Malaysia still practice face-to-face learning instead of using e-learning concepts especially in blended learning. This is evident in the statistics on e-learning in Malaysia where the use of learning methods is still at a moderate level of $35 \%$ compared to face-to-face and one-to-one learning with $100 \%$ and $40 \%$. In this regard, it is clear that the use of blended learning methods remains low despite the emphasis on e-learning (Embi and Assembly, 2010). Furthermore, according to a study by Said (2015) at the Polytechnic of Merlimau Melaka, where the level of lecturers' readiness for teaching and learning is at a moderate level. In addition, the results of the study on the faculties of the lecturers were also modest with a mean value of 3.52, followed by the level of lecturer preparation for blended learning with a mean of 3.34 , whereas the level of implementation of the blended learning is also modest with the lowest mean value of 3.32 .

Based on the CIDOS usage statistics for 2019 at Polytechnic Sultan Mizan Zainal Abidin (PSMZA), the level of usage of the CIDOS Platform blended learning is still at a moderate level. Therefore, the researcher wants to see the acceptability and effectiveness of blended learning activities at PSMZA.

\section{A. Previous Study}

Acceptance, Effectiveness and Relationship of Blended Learning Implementation Among Lecturers in Polytechnic Sultan Mizan Zainal Abidin 
This study focused on the PSMZA lecturers who are utilizing blended learning in teaching. The result cannot be generalized to the other polytechnics in Malaysia. In addition, based on Kerlinger (2000), the study used a self-reported questionnaire survey form are limited in nature by the accuracy of the participant response.

In Malaysian Polytechnic, Learning Management System (LMS) used in teaching and learning for Polytechnic lecturers is called Curriculum Information Document Online System (CIDOS). CIDOS is a medium of interaction between lecturers and students. CIDOS provides the interface to save, evaluate and share digital contents. The main function of CIDOS is to (CIDOS) facilitating the implementation of blended learning. In a study conducted by Nik Azida, Ahmad and Harith (2015) at the Ungku Omar School of Commerce, students gained positive perceptions about online assessment using blended learning.

In general, many previous studies have Izudin (2013) which reported increased motivation and performance as a result of blended learning. Gecer and Dag (2012) stated that students acknowledge that blended learning supports active learning and that the use of online materials is attractive. Similar findings were presented by Hubackova, Semradova, and Klimova (2011), when students were most likely to enjoy blended learning. The advantages of face-to-face learning and e-learning have been incorporated into blended learning to ensure learning achieves its goals. According to Yahaya and Ning (2011) among other visible effects of e-Learning implementation including the various $R \& D$ innovations can be generated directly to increase the confidence of the teaching staff for the purpose of delivering the course syllabus.

The findings of the recent study according to the study of Faridah et al (2012) show that students agree that the encouragement of the lecturers is convincing in their use of e-Learning. This shows that the role of lecturers is very important in increasing the effectiveness of e-Learning. Students find the instructional materials uploaded in eLearning by the lecturers help them learn a course independently and save cost when performing assessments such as assignments, quizzes, tests and other assignments. Nihra et al (2007) stated that the role of lecturers is very important in enhancing the effectiveness of e-learning. Students find the instructional materials uploaded in elearning by the lecturers help them to learn a course independently and save cost when implementing assessment tools.

\section{Importance of Study}

The importance of this study is that it will benefit stakeholders to identify the developmental stages of blended learning as a learning aid. The results of this study are expected to serve as a reference for Polytechnic Management to analyze the acceptability and impact on the implementation of blended learning among PSMZA lecturers. The findings of this study could be used by PSMZA to ensure lecturers practice using integrated online learning consistently without constraints. Lecturers in PSMZA can find

Acceptance, Effectiveness and Relationship of Blended Learning Implementation Among Lecturers in Polytechnic Sultan Mizan Zainal Abidin 
out the reality of conducting blended learning at this institution and further encourage them to produce materials or teaching aids in the future. The results of this study are also expected to be used as reference material by other educational institutions. In addition, it is hoped that it will serve as a guide to other researchers who wish to develop this study in the future.

\section{B. Hypothesis}

i. $\quad$ To identify the level of effectiveness in performing blended learning among PSMZA lecturers

ii. To identify whether teaching experience factor influence acceptance and effectiveness in the implementation of blended learning

\section{METHODOLOGY}

This chapter describes the focus and methods of research carried out for the purpose of data collection and analysis. Discussions are conducted under sub-headings such as study design, population, sample, research instrument, variables, data collection and analysis as a whole.

\section{Scope of the Study}

The study was conducted at PSMZA. The study sample consists of lecturers from various academic departments in PSMZA. The sample was selected based on the lecturers' feedback through online questionnaire. The aim of this study is to focus on the level of acceptance and effectiveness of blended learning in PSMZA from the lecturer's perspective.

\section{Model of Study}

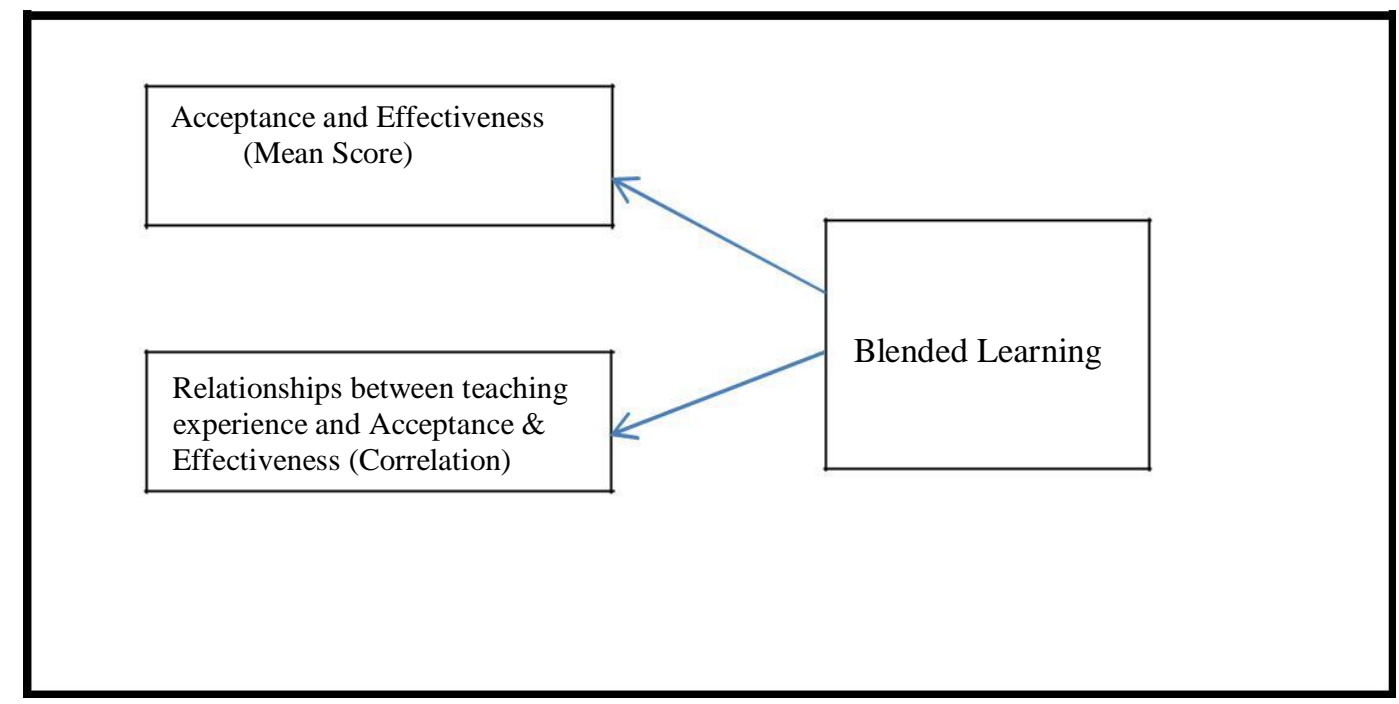

Adapted from : Amirudin, Rakemi dan Hidayat (2015)

Figure 1: Research Framework

Acceptance, Effectiveness and Relationship of Blended Learning Implementation Among Lecturers in Polytechnic Sultan Mizan Zainal Abidin 


\section{Design of the study}

Design of a study is a specific technique and method for obtaining information for problem solving. Through the techniques and methods selected will provide reliable and reliable insights. This study is descriptive through survey method using questionnaire form as a means of obtaining information. According to Chua (2006), the survey method using the questionnaire method is a data collection tool for a specific period of time, and it can explain the relevance of the pattern at a certain level.

\section{Population and sample}

The population of this study focuses on the whole of the lecturers who are directly involved in the teaching and learning activities. The population was obtained from the administration unit by the end of 2019, with data showing 270 academic lecturers in PSMZA. The questionnaire was distributed online through lecturers' emails and feedback of 190 questionnaire forms was obtained. However, only 181 questionnaire forms were used, which included some incomplete questionnaire forms for research data.

\section{Research instruments}

The use of the questionnaire instrument in this study is important because the quality of the questionnaire set determines the value of the research. The questionnaire was designed based on the objective of the study for the purpose of data collection. Researchers have formulated questions related to the respondents' information and two research questions on the acceptability and effectiveness of integrated learning among lecturers at the PSMZA. The questionnaire was divided into two sections where section I consisted of questions aimed at the respondents' background while section II consisted of two sections divided into 10 questions covering research questions related to the level of acceptance and effectiveness of the targeted learning practice.

\section{Data Analysis Procedures}

This questionnaire will be processed using SPSS software (Statistical Packages for Social Science version 20.0). The researcher uses mean score calculations, frequency values and percentages to analyze the collected data. If the mean value was between 1.00 and 2.40, the respondent group was considered to have a low level of competence, while the mean level would be recorded if the mean value was between 2.41 and 3.80. Finally, high values are recorded if the mean values are between 3.81 and 5.00. The relationship of the study factors is based on the initial hypothesis with the correlation coefficient of Pearson shape. Positive or negative coefficient values indicate that the high correlation between the 2 variables and the analytical findings will be compared with the original hypothesis that is considered as support and reference whether the findings are accepted or rejected.

\section{RESULTS AND DISCUSSION}

Acceptance, Effectiveness and Relationship of Blended Learning Implementation Among Lecturers in Polytechnic Sultan Mizan Zainal Abidin 


\section{Findings}

In this chapter the researchers discuss the conclusions and analyzes that has been conducted from the data obtained using SPSS 20.0.

\section{Respondents' Background Gender}

Table 1: Distribution of respondents by gender.

\begin{tabular}{ccc}
\hline Gender & Respondent & Percent (\%) \\
\hline Male & 70 & 39 \\
Female & 111 & 61 \\
Total & 181 & 100 \\
\hline
\end{tabular}

According to table 1 above, the number of respondents from female lecturers is greater than $22 \%$ by male lecturers. A total of 111 female lecturers represented $61 \%$, while 70 male lecturers represented $39 \%$.

\section{Academic Qualifications}

Table 2: Distribution of respondents based on academic qualifications

\begin{tabular}{ccc}
\hline Academic Qualifications & Respondent & Percent (\%) \\
\hline Ph.D & 3 & 2 \\
Masters & 86 & 48 \\
Bachelor & 87 & 48 \\
Diploma & 5 & 3 \\
Total & 181 & 100 \\
\hline
\end{tabular}

According to table 2 above, it is shown that the highest number of respondents with bachelor's degree as teaching qualification is $48 \%$ representing 87 persons, while respondents with 3 doctoral academic qualifications of $2 \%$ and $86 \%$ academic qualification represent $48 \%$ of overall respondents. In addition, respondents with a diploma of 5 lecturers representing $3 \%$.

\section{Teaching Experience}

Table 3: Distribution of respondents based on teaching experience.

\begin{tabular}{ccc}
\hline Teaching experience & Respondent & Percent $(\%)$ \\
\hline Below 5 years & 0 & 0 \\
6 to 10 years & 38 & 21 \\
11 to 15 years & 92 & 51 \\
Above 16 years & 51 & 28 \\
Total & 181 & 100 \\
\hline
\end{tabular}

Acceptance, Effectiveness and Relationship of Blended Learning Implementation Among Lecturers in Polytechnic Sultan Mizan Zainal Abidin 
Table 3 shows that the 11 to 15 years teaching experience category was the highest with $51 \%$ of 92 people, while the teaching experience between 6 and 10 years was the lowest with $21 \%$ representing 38 respondents.

\section{Academic Department}

Table 4: Distribution of respondents by department.

\begin{tabular}{|c|c|c|}
\hline Academic Department & Respondent & Percent $(\%)$ \\
\hline Civil Engineering & 29 & 16 \\
\hline Electrical Engineering & 27 & 15 \\
\hline Mechanical Engineering & 49 & 27 \\
\hline Mathematics, Science and Computer & 24 & 13 \\
\hline Information and Communication Technology & 24 & 13 \\
\hline General Studies & 24 & 15 \\
\hline Total & 181 & 100 \\
\hline
\end{tabular}

Table 4 shows the distribution of respondents by category of academic departments. Respondents from the Department of Mechanical Engineering had the highest response rate of 49 lecturers. The lowest were from the Department of General Studies, Mathematics, Science and Computer and Information and Communication Technology, accounting for 24 lecturers, accounting for $13 \%$ of the total respondents.

\section{Findings Analysis}

The second part of the study consisted of 10 question items divided into two sections according to the research questions to determine the level of acceptance and effectiveness of blended learning. The analysis of the findings of the first part was evaluated based on the following mean scores:

\begin{tabular}{lc} 
Table 5: Mean Score Interpretation \\
Mean value & Description \\
\hline $1.00-2.33$ & Low \\
$2.34-3.67$ & Medium \\
$3.68-5.00$ & High \\
\hline \multicolumn{2}{c}{ Source: Landell (1977) }
\end{tabular}

While the second study was analyzed based on the following Pearson correlation coefficient:

\begin{tabular}{|c|c|}
\hline Correlation coefficient & Interpretation Correlation \\
\hline$<0.20$ & Negligible relationship \\
\hline $0.20-0.40$ & Low relationship \\
\hline $0.41-0.70$ & Moderate relationship \\
\hline $0.70-0.90$ & Moderate relationship \\
\hline$>0.90$ & Negligible relationship \\
\hline
\end{tabular}

Acceptance, Effectiveness and Relationship of Blended Learning Implementation Among Lecturers in Polytechnic Sultan Mizan Zainal Abidin 


\section{Analysis of Acceptance and Effectiveness of Blended Learning}

This section contains 10 question items related to the acceptance and effectiveness of blended learning. The data analyzed using mean values and the results of the study are as follows:

Table 7: Acceptance Level

\begin{tabular}{llccc}
\hline \multicolumn{1}{c}{ Item } & $\mathrm{N}$ & Mean & SD \\
\hline 1. I have been practicing blending learning for the past 5 years. & 181 & 3.81 & 0.849 \\
2. I am happy to be able to carry out online learning activities. & 181 & 3.76 & 0.841 \\
3. I always give a notes to students using blended learning & 181 & 3.64 & 0.999 \\
$\begin{array}{l}\text { through CIDOS. } \\
\text { 4. I enjoy teaching and learning activities using blended } \\
\text { learning. }\end{array}$ & 181 & 3.61 & 0.940 \\
5. The learning environment is more interesting by using \\
blended learning methods.
\end{tabular}

Table 7 shows the analysis of the level of acceptance related to the implementation of blended learning among the PSMZA lecturers. Items 1 and 2 were at the high mean score levels of 3.81 and 3.76 while mean scores for items 3, 4 and 5 were in the moderate range of 3.64, 3.60 and 3.61. Items that have the highest mean score for the questionnaire have a mean score of 3.81 .

Table 8: Effectiveness Level

\begin{tabular}{rlrcc}
\hline \multicolumn{1}{c}{ Item } & $\mathrm{N}$ & Mean & SD \\
\hline 1. $\quad \begin{array}{l}\text { The blended learning process enhances the confidence of the } \\
\text { lecturer in the teaching and learning process. } \\
\text { The teaching and learning process can be implemented more } \\
\text { effectively through blended learning. }\end{array}$ & 181 & 3.73 & 0.855 \\
3. $\quad \begin{array}{l}\text { A variety of learning activities can be applied through this } \\
\text { blended learning. }\end{array}$ & 181 & 3.69 & 0.827 \\
4. $\quad \begin{array}{l}\text { Student assessment activities can be carried out more easily } \\
\text { and quickly by using blended learning. }\end{array}$ & 181 & 3.82 & 0.841 \\
5. $\quad \begin{array}{l}\text { I regularly practice this blended learning because it } \\
\text { attracts students to learn more effectively. }\end{array}$ & 181 & 3.55 & 0.980 \\
\hline
\end{tabular}

According to table 8 above, analyzes of the variables of the level of effectiveness of the implementation of blended learning among the PSMZA lecturers showed that the mean scores for each of item items $1,2,3$ and 4 were high at 3.69 to 3.88 while the mean scores for question 5 items were within a moderate level of 3.55. The highest scoring question items were item 3 in which 85 lecturers expressed agreement for this question item. This indicates that most respondents agree a variety of learning activities can be applied through this blended learning.

\section{Correlation Analysis}

Acceptance, Effectiveness and Relationship of Blended Learning Implementation Among Lecturers in Polytechnic Sultan Mizan Zainal Abidin 
The analysis uses Pearson correlation to see the relationship between teaching experience variables on acceptance and effectiveness. Table 9 shows that the two variables have a correlation value of less than 0.20. According to Guilford's (1970) interpretation table, the correlation coefficient less than 0.20 indicate that there is no correlation between these two coefficients. This shows that the teaching experience does not influence the acceptance and effectiveness of the lecturers towards the implementation of the blended learning in PSMZA. There is no statistically significant correlation between teaching experience and acceptance level of blending learning in PSMZA's teaching staff. The same observation also found for correlation between teaching experience and the effectiveness of blending learning. Refer to Table 9.

Table 9: Relationship of teaching experience to acceptance and effectiveness

\begin{tabular}{ccc}
\hline Variable & Correlation Coefficient & $p$-value \\
\hline Acceptance & -0.108 & 0.148 \\
Effectiveness & -0.068 & 0.365
\end{tabular}

\section{Discussion}

Data analysis shows a high mean score for the acceptance of lecturers who have practiced blended learning for the past 5 years. In addition, lecturers enjoyed the use of blended learning and were frequently providing notes through CIDOS. This is because the high mean scores for all three items indicate no significant differences. The positive reception by the respondents showed that the learning of the mix greatly helped the teaching and learning process in polytechnics. Yusuf (2011) also argues that the CIDOS platform developed is a blended learning method developed for the use of lecturers for all polytechnics in Malaysia. In the study of the effectiveness of the blended learning method, the result has clearly shown that the respondents agree that student assessment activities using blended learning very helpful. The process of assessing students will be easier and faster using blended learning with a variety of activities.

The findings of this correlation test mean that the use of blended learning cannot be restricted by teaching experience and various teaching and learning activities using blended learning should be widely used in PSMZA. In addition, the results of this study were supported by Nihra e.t al, (2007) who stated that the role of lecturers is very important in enhancing the effectiveness of e-learning.

\section{CONCLUSION}

Based on this study, the researcher has discussed the objectives, methodology, findings and discussion on the level of acceptance and effectiveness of blended learning in PSMZA. Positive findings were recorded where the level of acceptance and effectiveness is at a high level. Pearson correlation analysis has shown that there is no relationship

Acceptance, Effectiveness and Relationship of Blended Learning Implementation Among Lecturers in Polytechnic Sultan Mizan Zainal Abidin 
between teaching experience towards acceptance and effectiveness of blended learning the implantation of the blended learning in PSMZA.

\section{ACKNOWLEDGEMENTS}

This paper has no conflict of interest.

\section{REFERENCES}

Amin, M., Implementation of e-Learning Using SPIN. Effective Teaching \& Learning Practices Guide. City,

pp. 161-174, (2010)

Azida,N., Ahmad,T. and Harith, F., Blended Learning: Implementation of Online Assessment, Advanced

Journal of Technical and Vocational Education, 2015 October; 1(2): pp. 44-49, (2015).

CAP eLearning, National e-Learning Policy (DePAN). National e-Learning Basic Book (DePAN), Kementerian Pengajian Tinggi Malaysia, (2014).

Chua, Y. P., Basics of Research Statistics. Kuala Lumpur, McGraw-Hill (Malaysia) Sdn Bhd, (2006).

Faridah, J., and Zain, R., Readiness for E-Learning Use in Polytechnic Students, Ministry of Higher Education. Department of Polytechnic Studies. Journal of Education. KPT6044, (2012).

Garrison, R., Vaughan, N., Blended Learning in Higher Education: Framework, Principles, and Guidelines. USA: John Wiley \& Sons, (2011).

Gecer, A., and Dag, F., A Blended Learning Experience. Educational Sciences: Theory and Practice, 12(1), pp. 438-442, (2012).

Gecer, A., Lecturer-Student Communication in Blended Learning Environments. Educational Consultancy and Research Center, 13 (1): pp. 362-367, (2013).

Guilford, J. P., and Fruchter, B., Fundamental statistics in psychology and education (5th ed.). McGraw-Hill, (1973).

Hashim, S., A Study Of Student Satisfaction In a Blended Learning System Environment. Bachelor of Education Thesis. UiTM, (2014).

Hubackova, S., Semradova, I., and Klimova, B. F., Blended Learning in Foreign Language Teaching. Procedia-

Social and Behavioral Sciences, 28, pp.281-285, (2011).

Hussin, Z., Siraj, S., Darusalam, G., and Salleh, N. H., Blended Learning Model Study in Selected Journals: An Content Analysis. Asia Pacific Curriculum \& Teaching Journal, Bil 1(2), pp. 20-31, (2013).

Izudin, S., Influence of Blended Learning Models on Motivation and Student Learning Performance.

Acceptance, Effectiveness and Relationship of Blended Learning Implementation Among Lecturers in Polytechnic Sultan Mizan Zainal Abidin 
Journal of Vocational Education, 2(2), (2013).

Kerlinger, F.N, and Lee, H.P., Foundation of Behavioral Research, (4th Ed). Forth Worth, TX: Harcpour, (2000). Landell, K., Management by menu. London: Wiley and Sons Inc, (1997).

Mahajan T., \& Chaturdevi S., Impact Study of Blended Learning on Functional Effectiveness Factor of Managerial Effectiveness. Journal of Management Research, 13 (4): pp. 209-218, (2013).

Nihra, M.H., Norazean, H.J., Influence of Blended Learning Models on Motivation and Student Learning Performance. Journal of Vocational Education. Presented at 1st International Malaysian Educational Technology Convention, (2007).

Noraffandy Y., and Ling N., N., Preparedness for E-Learning Using Two Year Bachelor's Degree in Computer Science and Education, Faculty of Education, University of Technology Malaysia-A Review. Jurnal of Educational Social Science, volume 1 Mac 2011, Pages 121-140 / ISSN: 2231-7333, (2011).

Omar, R., and Ahmad, J. H., Evaluation and Acceptance of e-Learning in Academic Circles. Journal of Malaysian Education ,34(1), pp. 155-172, (2009).

Osgerby, J., Students' Perceptions of The Introduction Of A Blended Learning Environment: An exploratory case study. Accounting Education: An International Journal, 22 (1): pp. 85-99, (2013).

Said, H., Lecturer's Readiness for Blended Learning Implementation at Merlimau Polytechnic Melaka. Politeknik Merlimau Melaka, (2015).

Shukri, M., Anuar, M., and Shiung, T., K., Research on Use of E-Learning Among Students in Technical and Vocational Education at State Higher Education Institution (IPTA) Johor, Presented at 1st International Malaysian Educational Technology Convention, (2015).

Yu, C., K., Belland, B., Kerstin E., Schroder, K., and Walker, A., E., K-12 Teachers' Perceptions of and Their

Satisfaction with Interaction Type in Blended Learning Environments. Distance Education, 35 (3): pp. 360381, (2014).

Yusof, Y., T., New Year Message 2011. City, (2011).

Acceptance, Effectiveness and Relationship of Blended Learning Implementation Among Lecturers in Polytechnic Sultan Mizan Zainal Abidin 